\title{
Pelatihan Pembelajaran IPA Berbasis Inkuiri Berbantuan KIT Bagi Guru- Guru SD Di Kota Mataram
}

\author{
Sutrio $^{1 *}$, Hairunnisyah Sahidu ${ }^{1}$, Ahmad Harjono ${ }^{1}$, I Wayan Gunada ${ }^{1}$, Hikmawati ${ }^{1}$ \\ ${ }^{1}$ Program Studi Pendidikan Fisika, FKIP Universitas Mataram, Mataram, Indonesia
}

DOI: https://doi.org/10.29303/jpmsi.v2i2.80

Citation: Sutrio, S., Sahidu, H., Harjono, A., Gunada, I. W., Hikmawati, H. 2020. Pelatihan Pembelajaran IPA Berbasis Inkuiri Berbantuan KIT bagi Guru-guru SD di Kota Mataram. Jurnal Pengabdian Masyarakat Sains Indonesia (JPMSI). 147-153.

Article history

Received: November $10^{\text {th }} 2020$

Revised: November $17^{\text {th }} 2020$

Accepted: November $23^{\text {th }} 2020$

*Corresponding Author:

Sutrio, FKIP Universitas

Mataram, Mataram, Indonesia; Email: sutrio_trio@unram.ac.id

\section{Pendahuluan}

Pemerintah melalui Undang-Undang No 20 Tahun 2003 tentang Sistem Pendidikan Nasional mengupayakan adanya peningkatan kualitas pendidikan di Indonesia. Indikator keberhasilan pendidikan nasional di Indonesia dituangkan dalam Peraturan Pemerintah nomor 19 tahun 2004 tentang Standar Nasional Pendidikan. Ada delapan standar yang ditetapkan oleh pemerintah untuk mengarahkan pelaksanaan pendidikan yang berkualitas. Salah satu standar yang paling penting untuk diperhatikan adalah standar pendidik dan kependidikan. Seorang pendidik harus memiliki kompetensi sebagai agen pembelajaran pada jenjang pendidikan dasar dan menengah serta pendidikan anak usia dini, yaitu kompetensi peadagogik, kompetensi kepribadian, kompetensi profesional, dan kompetensi sosial. Berkaitan dengan kualitas pendidikan, Ada empat (4) standar kualitas pendidikan dalam urutan prioritasnya adalah (1) guru, (2) kurikulum, (3) atmosfer akademik, dan (4) sumber keilmuan.

Upaya peningkatan kualitas pendidikan dapat di tempuh dengan beberapa cara antara lain: peningkatan kualitas guru, peningkatan materi, peningkatan dalam pemakaian metode, peningkatan sarana, dan peningkatan kualitas belajar. Peningkatan kualitas guru harus senantiasa dilakukan karena guru merupakan ujing tombak pendidikan. Dalam UU No. 14 Tahun 2005 tentang guru dan dosen, dinyatakan bahwa guru adalah pendidik profesional yang tugas utamanya adalah mendidik, mengajar, membimbing, mengarahkan, melatih, menilai, dan mengevaluasi peserta didiknya. Pekerjaan profesional yang dimaksud dalam UU tersebut adalah pekerjaan yang dilakukan seseorang dalam usaha meningkatkan kehidupan, yang membutuhkan keterampilan dan keahlian yang memenuhi standar kualitas yang berlaku. 
Sutrio et al, Jurnal Pengabdian Masyarakat Sains Indonesia 2020, 2 (2):147-153. DOI : https://doi.org/10.29303/jpmsi.v2i2.80

Berdasarkan uraian di atas dapat ditarik kesimpulan bahwa peningkatan kualitas pendidikan akan bermuara pada peningkatan kualitas pembelajaran di kelas. Dengan kata lain, peningkatan kualitas pendidikan banyak ditentukan oleh kualitas pembelajaran yang dilakukan oleh guru-peserta didik di kelas. Guru memiliki posisi yang sangat penting dan strategi dalam pengembangan potensi yang dimiliki peerta didik. Pada diri gurulah kejayaan dan keselamatan masa depan bangsa dengan penanaman nilai-nilai dasar yang luhur sebagai cita-cita pendidikan nasional dengan membentuk kepribadian sejahtera lahir dan bathin, yang ditempuh melalui pendidikan di sekolah.

Guru adalah tenaga pendidik yang dituntut memiliki kompetensi pedagogik, profesional, sosial dan kepribadian. Tugas pokok dan fungsi guru sesuai dengan Permendikbud No.15 Tahun 2018 adalah mendidik, mengajar, membimbing, mengarahkan, melatih, menilai, dan mengevaluasi peserta didik. Seiring dengan perkembangan ilmu pengetahuan dan teknologi guru dituntut dalam menjalankan tugasnya adaptif, inovatif, kreatif dan kritis dalam proses pembelajaran (Rahman, 2019)

Upaya peningkatan kualitas guru telah dilakukan oleh pemerintah melalui berbagai pelatihan atau penataran dan studi banding dengan sekolah-sekolah di daerah atau Negara lain. Namun kegiatan untuk peningkatan kualitas guru semacam ini baru dirasakan oleh sedikit guru karena terkendala banyak hal. Tidak meratanya kegiatan untuk peningkatan kualitas guru ini juga menyebabkan tidak meratanya kualitas guru dalam membelajarkan materi pelajaran khususnya muatan pelajaran IPA.

Pembelajaran di sekolah sangat ditentukan oleh guru. Guru sebagai ujung tombak dalam pelaksanaan pendidikan merupakan pihak yang sangat berpengaruh dalam proses pembelajaran. Guru diberikan kebebasan dalam memilih model pembelajaran yang akan diterapkan dalam proses pembelajaran. Guru harus mampu menggunakan model pembelajaran yang dapat dipadukan dengan pendekatan saintifik sebagai pendekatan yang utama dalam proses pembelajaran. Model pembelajaran yang sesuai dengan pendekatan saintifik, antara lain: model pembelajaran inkuiri, model pembelajaran penemuan, model pembelajaran berbasis masalah, dan model
e-ISSN : 2715-2537

p-ISSN : 2715-2545

pembelajaran berbasis proyek (Permendikbud No. 103 Tahun 2014)

Ilmu Pengetahuan Alam (IPA) mempunyai peranan yang sangat penting dalam segala aspek kehidupan. Proses pembelajaran IPA atau Sains bertujuan supaya peserta didik dapat mencapai literasi sains, sehingga mampu menciptakan masyarakat Indonesia yang melek sains. Pentingnya pembelajaran IPA bagi kehidupan masyarakat, maka diperlukan peningkatan kualitas pembelajaran secara konsisten. Peningkatan kualitas pembelajaran IPA khususnya untuk pendidikan dasar dilakukan secara terpadu, scientific aprpoach salah satunya dengan inkuiri sains, tema sains, dan ketrampilan berpikir sains. Pengembangan berpikir sains dapat meningkatkan kemampuan berpikir tingkat tinggi peserta didik termasuk di dalamnya critical thingking skills atau ketrampilan berpikir kritis (Asy'ari, 2006)

Muatan Pelajaran IPA di Sekolah Dasar (SD) bertujuan agar peserta didik memahami konsep-konsep IPA, memiliki keterampilan proses, mempunyai minat mempelajari alam sekitar, bersikap ilmiah, mampu menerapkan konsepkonsep IPA untuk menjelaskan gejala-gejala alam dan memecahkan masalah dalam kehidupan seharihari, mencintai alam sekitar, serta menyadari kebesaran dan keagungan Tuhan. Berdasarkan tujuan tersebut, maka pembelajaran IPA di SD membutuhkan proses belajar mengajar yang tidak terlalu akademis dan verbalistik (Poedjiati, 2005) Oleh karena itu salah satu model pembelajaran yang dapat digunakan untuk meningkatkan kemampuan pemecahan masalah dan kompetensi pengetahuan muatan IPA di sekolah dasar adalah model pembelajaran berbasis inkuiri berbantuan KIT.

Model pembelajaran inkuiri adalah suatu model pembelajaran yang dikembangkan agar siswa menemukan dan menggunakan berbagai sumber informasi dan ide-ide untuk meningkatkan pemahaman mereka tentang masalah, topik, atau isu tertentu (Abidin, 2014:149). Langkah-langkah dalam model pembelajaran inkuiri terdiri dari (1) penyajian informasi, (2) menyajikan pertanyaan atau masalah, (3) membuat hipotesis, (4) pengumpulan data, (5) penyajian data, dan (6) membuat kesimpulan (Kurniasih dan Sani, 2015:115-117). Dalam tahap pengumpulan datadata yang menunjang pemecahan masalah, salah satu metode yang tepat digunakan dalam 
Sutrio et al, Jurnal Pengabdian Masyarakat Sains Indonesia 2020, 2 (2):147-153. DOI : https://doi.org/10.29303/jpmsi.v2i2.80

mengumpulkan data tersebut dengan menggunakan metode eksperimen/percobaan. Dalam melakukan percobaan IPA penggunaan KIT sangat diperlukan. Untuk melaksanakan percobaan bisa dibuatkan Lembar Kerja Peserta Didik berbasis Inkuiri. Hikmawati et. al. (2018) Lembar Kerja Peserta Didik Berbasis Inkuri (LKPD BI) merupakan lembaran yang berisi panduan bagi peserta didik untuk melakukan kegiatan penyelidikan menggunakan keterampilan proses melalui aktivitas merumuskan masalah, membuat hipotesis, melaksanakan percobaan, mengumpulkan dan mengolah data, dan mengkomunikasikan hasil temuannya dalam masyarakat belajar

Penyampaian materi IPA hanya dengan metode ceramah dan pengerjaan soal cenderung membuat peserta didik bosan dan penyerapan materi oleh peserta didik kurang maksimal. Penyampaian materi dengan memberikan pengalaman langsung kepada peserta didik melalui penggunaan KIT dan media yang ada di sekitar peserta didik merupakan salah satu alternatif dalam pembelajaran IPA. Penggunaan media pembelajaran berupa KIT IPA diharapkan dapat memberikan bekal keterampilan proses peserta didik dan menunjang terserapnya materi IPA untuk peserta didik. Sehingga nantinya peserta didik mampu mengembangkan pengetahuannya melalui proses-proses sains dan berpikir ilmiah dalam kehidupan sehari-hari.

Berawal dari maksud mencapai tujuan pembelajaran IPA, beberapa SD telah memiliki KIT IPA, namun berdasarkan informasi yang diperoleh, belum semua guru SD memanfaatkan alat peraga yang telah dimilikinya tersebut. Berbagai kendala yang dijumpai dalam pemakaian alat peraga dalam proses belajar-mengajar IPA di SD antara lain: (1) Para Guru kurang mengenal alat-alat dalam KIT IPA SD; (2) Para Guru belum terlatih menggunakan alat peraga IPA; (3) Para Guru tidak berani mencoba menggunakan KIT IPA SD yang tersedia karena takut rusak. Di beberapa SD di gugus IV Cakranegara kota Mataram terdapat peralatan KIT IPA dari hasil pegadaan melalui dana BOS dan beberapa peralatan KIT yang disediakan oleh pemerintah namun pemanfaatan di dalam kegiatan pembelajaran masih kurang maksimal. Hasil wawancara dengan Ka SD Inti selaku ketua Gugus banyak guru-guru yang belum mengenal alat-alat dalam KIT, belum terlatih menggunakan peralatan di dalam proses pembelajaran secara maksimal, dan
e-ISSN : 2715-2537

p-ISSN : 2715-2545

kekawatiran menggunakan peralatan karena takut rusak.

Hal tersebut tentu saja dapat menghambat pengembangan kemampuan saintifik guru. Dibutuhkan suatu dorongan guna mengurangi atau menghilangkan kendala tersebut, agar nantinya guru dapat meningkatkan kemampuan saintifik yang dimilikinya. Dorongan tersebut dapat berupa kegiatan yang dikemas dalam bentuk pelatihan penggunaan KIT IPA SD, sebagai treatment yang dilakukan kepada guru-guru SD dalam sebuah kegiatan pengabdian.

Berdasarkan analisis situasi dan permasalahan yang dialami oleh guru-guru SD di gugus IV Kecamatan Cakranegara Kota Mataram , maka diperlukan upaya dari berbagai pihak untuk memberikan solusi permasalahan termasuk Perguruan Tinggi. Salah satu alternatif yang dapat dilakukan untuk mengatasi permasalahan guru tersebut adalah solusi yang ditawarkan memberikan pelatihan bagaimana cara menggunakan KIT IPA dan memberikan pendampingan kepada para guru melakukan kerja praktik sesuai dengan yang ada di dalam KIT serta mencoba menerapkan penggunaan KIT dalam pembelajaran IPA berbasis Inkuiri. Dalam kegiatan ini setelah peserta terampil menggunakan KIT IPA diharapkan guru dapat menerapkan dalam pembelajaran IPA berbasis Inkuiri.

\section{Metode}

Kegiatan ini dilaksanakan di Sekolah Dasar mitra Gugus IV Cakranegara. Di masa pandemi virus corona mengingat pelaksanaan harus menggunakan protokol kesehatan sasaran pelatihan dibatasi hanya untuk guru-guru di SDN 1 Cakranegara sebagai SD inti. Hasil pelatihan yang diperoleh bisa di imbaskan ke guru-guru SD lainnya dalam Gugus. Metode pelaksanaan kegiatan pengabdian ini dibagi menjadi 6 (enam) tahap kegiatan. Adapun tahapan kegiatan sebagai berikut:

1. Pada awal kegiatan mengumpulkan ide, permasalahan yang ditemui dalam pembelajaran di sekolah yang dihadapi oleh Guru. Pada kegiatan ini guru mengisi Google Formulir yang berisi pertanyaan-pertanyaan terkait permasalahan penggunaan KIT dan penerapan model pembelajaran berbasis inkuiri yang diberikan sebelum pelaksanaan pelatihan. 
Sutrio et al, Jurnal Pengabdian Masyarakat Sains Indonesia 2020, 2 (2):147-153. DOI : https://doi.org/10.29303/jpmsi.v2i2.80

2. Pengenalan Komponen alat dalam kotak KIT IPA. Guru diperkenalkan komponen-komponen alat dan fungsinya serta penggunaannya dalam pembelajaran IPA serta penjelasan bagaimana memelihara dan merawat alat dari kerusakan.

3. Mensimulasikan penggunaan KIT IPA dalam kegiatan pembelajaran berbasis inkuiri. Guru mengamati pemodelan pembelajaran IPA berbasis inkuiri berbantuan KIT yang dilakukan oleh Tim Pengabdian.

4. Diskusi pembelajaran berbasis inkuiri berbantuan KIT. Setelah pemodelan pembelajaran IPA guru diajak berdiskusi pengalaman menerapkan pembelajaran inkuiri apakah tahapan-tahapannya yang dilakukan oleh guru sudah sesuai dengan yang dimodelkan. Pada akhir kgiatan tahapan ini dipresentasikan teori pembelajaran berbasis inkuiri.

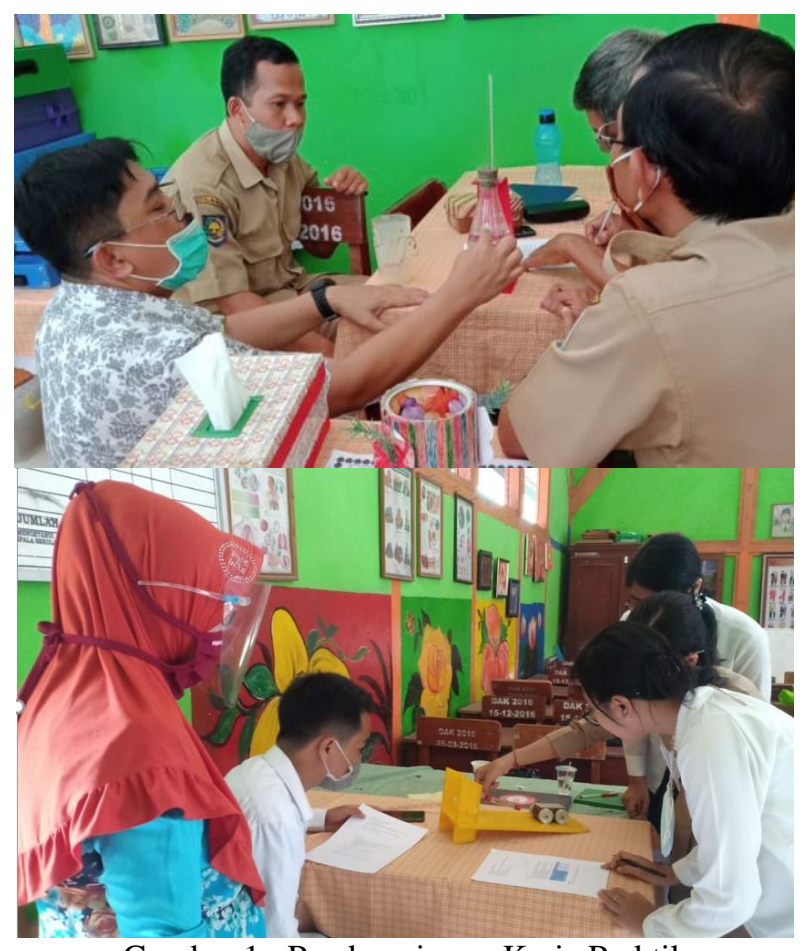

Gambar 1. Pendampingan Kerja Praktik

5. Pendampingan Kerja praktik berkelompok menggunakan KIT untuk menemukan konsepkonsep IPA dan penerapannya dalam pembelajaran. Pada kegiatan ini peserta melakukan kerja praktik secara berkelompok dengan melakukan percobaan dengan pendampingan oleh Tim Pengabdian untuk
e-ISSN : $2715-2537$

p-ISSN : 2715-2545

menemukan konsep-konsep IPA (lihat Gambar 1)

6. Evaluasi kegiatan membahas aspek positif dan aspek negatif kegiatan pelatihan serta saran untuk kegiatan selanjutnya. Guru menuliskan aspek positif/manfaat yang diperoleh dalam mengikuti kegiatan pelatihan, aspek negatif/kekurangan dalam pelaksanaan pelatihan baik dari pihak Tim pengabdian atau guru sendiri serta saran apabila ada kegiatan pelatihan yang serupa dan tindak lanjut yang akan dilakukan oleh guru setelah selesai pelatihan.

\section{Hasil dan Pembahasan}

Pada awal kegiatan diperoleh hasil analisis isian Google Form yang disisi oleh guru-guru sebelum pelaksanaan pelatihan yang dapat dilihat pada Tabel 1.

Tabel 1. Hasil Analisis Permasalahan Pembelajaran di Sekolah.

\begin{tabular}{|c|c|c|c|}
\hline \multirow{2}{*}{ Pertanyaan } & \multicolumn{3}{|c|}{ Prosentase } \\
\hline & ya & mungkin & tidak \\
\hline $\begin{array}{l}\text { Apakah bapak/ ibu } \\
\text { mengetahui tentang } \\
\text { pembelajaran } \\
\text { berbasis inkuiri? }\end{array}$ & $93,3 \%$ & $6.7 \%$ & $0 \%$ \\
\hline $\begin{array}{l}\text { Apakah bapak/ ibu } \\
\text { menerapkan } \\
\text { pembelajaran } \\
\text { berbasis inkuiri } \\
\text { dalam pembelajaran } \\
\text { di kelas selama ini? }\end{array}$ & $46.7 \%$ & $46,7 \%$ & $6,6 \%$ \\
\hline $\begin{array}{l}\text { Apakah bapak/ibu } \\
\text { dalam melaksanakan } \\
\text { pembelajaran } \\
\text { menggunakan KIT } \\
\text { IPA? }\end{array}$ & $40 \%$ & $40 \%$ & $20 \%$ \\
\hline $\begin{array}{l}\text { Apakah bapak ibu } \\
\text { mengalami kesulitan } \\
\text { dalam menggunakan } \\
\text { KIT IPA? }\end{array}$ & $73,3 \%$ & $0 \%$ & $26,7 \%$ \\
\hline
\end{tabular}

Hasil analisis lainnya berkaitan dengan permasalahan KIT IPA yang dialami guru sebagai berikut : (1) ada beberapa komponen Kit IPA belum tahu nama dan fungsinya , (2) kurang mengerti cara menggunakan KIT IPA, dan (3) mengalami kesulitan dalam pengoperasian KIT IPA saat menjelaskan kepada peserta didik. Berdasarkan 
hasil analisis permasalahan di atas guru sangat perlu diberikan kegiatan pelatihan seperti yang sudah dirancang oleh Tim Pengabdian.

Pengenalan Komponen KIT IPA dilakukan dengan cara meminta terlebih dahulu kepada guru untuk menyebutkan alat dan fungsinya. Beberapa peserta sudah tahu nama alat dan fungsinya sedangkan yang lainnya ada yang belum tahu. Oleh karena itu perlu dijelaskan nama alat dan fungsinya serta ditunjukkan cara menggunakan dan merakit KIT tersebut. Hal-hal penting terkait dengan pemeliharaan dan perawatan alat juga dijelaskan, mengingat peralatan KIT ada yang rawan pecah/rusak dan membahayakan.

Simulasi pembelajaran yang dilakukan oleh tim pengabdian dengan melakukan kegiatan peerteacing materi bunyi. Guru dilibatkan sebagi peserta didik dan salah satu tim sebagai guru model. Dalam pelaksanaan terlihat bahwa guru perlu mendapatkan bimbingan penggunaan KIT IPA dan pembimbingan untuk menemukan konsepkonsep IPA. Setelah selesai pembelajaran guru diajak berdiskusi dan memberi komentar terkait pemodelan pembelajaran berbasis inkuiri berbantuan KIT. Beberapa guru memperoleh hasil pemahaman pembelajaran berbasis inkuiri terutama tahapan pembelajarannya. Guru menyadari walaupun merasa telah menerapkan pembelajaran berbasis inkuiri ternyata tahapantahapan yang dilakukan masih ada yang terlewati.

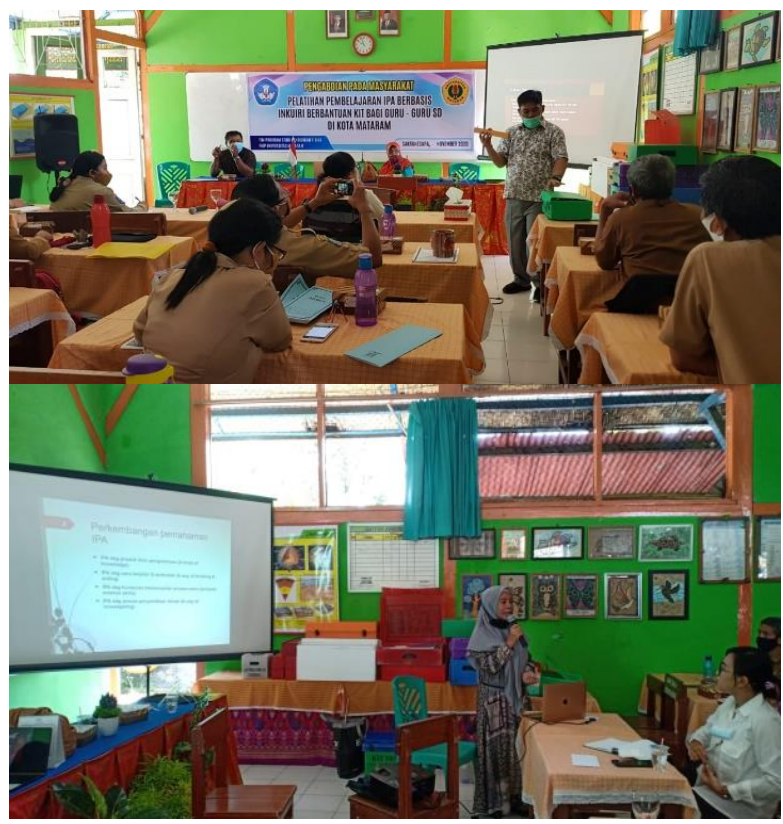

Gambar 2. Simulasi dan Diskusi Pembelajaran IPA Berbasis Inkuiri berbantuan KIT
Kegiatan praktik penggunaan KIT IPA yang dilakukan secara berkelompok merupakan kegiatan yang menarik bagi guru. Guru mencoba melakukan percobaan untuk menemukan konsepkonsep IPA. Dalam kegiatan ini dilakukan pendampingan dan arahan dalam mengelola percobaan IPA dan diskusi konsep-konsep IPA. Guru sangat antusias mengikuti kegiatan dan tertantang untuk menemukan konsep-konsep IPA. Hasil yang diperoleh untuk kegiatan ini guru telah mencoba melakukan beberapa percobaan seperti pecobaan tentang bunyi, panas, pesawat sederhana. Dalam diskusi juga guru menyadari bahwa dalam pembelajaran mengalami miskonsepsi dan dengan melakukan percobaan IPA dengan menggunakan KIT dapat membetulkan miskonsepsi yang mereka alami. Hal ini akan berdampak guru dapat membelajarkan konsep-konsep IPA dengan benar.

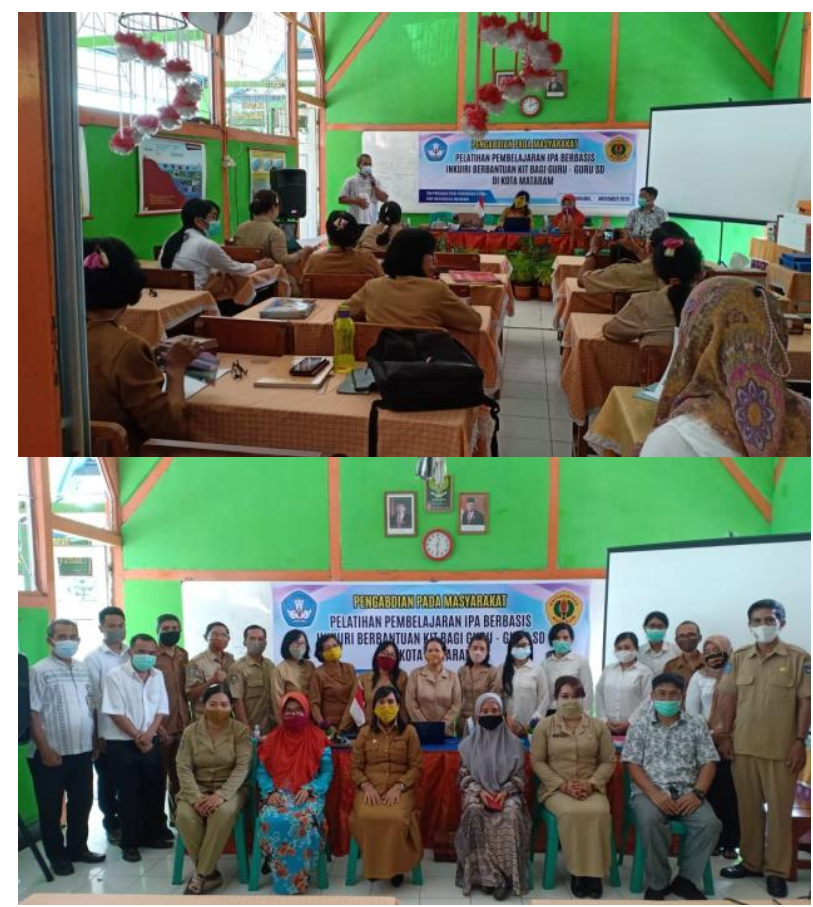

Gambar 3. Kegiatan evaluasi pelatihan dan Foto Bersama Peserta Pelatihan

Hasil evaluasi yang dilakukan setelah selesai pelatihan guru-guru menyampaikan aspekaspek positif kegiatan pelatihan sebagai berikut : (1) Memeproleh banyak pengetahuan dalam menggunakan KIT IPA dalam pembelajaran dan mengkaitkannya dengan kehidupan sehari-hari, (2) Mendapatkan pengetahuan baru mengenai penggunaan KIT IPA dalam pembelajaran dan akan menerapkannya di dalam pembelajaran, 
Sutrio et al, Jurnal Pengabdian Masyarakat Sains Indonesia 2020, 2 (2):147-153. DOI : https://doi.org/10.29303/jpmsi.v2i2.80

Memperoleh pengetahuan tentang model pembelajaran inkuiri dan pengetahuan tentang penggunaan KIT IPA serta penerapan KIT IPA dalam pembelajaran berbasis inkuiri, (4) Pengetahuan guru menjadi meningkat dan apabila model pembelajaran inkuiri berbantuan KIT IPA diterapkan maka kegiatan pembelajaran menjadi menyenangkan bagi peserta didik, (5) Mendapatkan tambahan ilmu untuk memperluas wawasan tentang penggunaan KIT IPA, (6) Dapat mengetahui namanama komponen alat-alat dalam KIT IPA, (7) Mempermudah menjelaskan konsep-konsep IPA kepada peserta didik dengan menggunakan KIT, (8) Menambah pengetahuan tentang pembelajaran berbasis inkuir, (9) Dapat menggunakan alat/KIT IPA dengan benar, (10) Memperoleh pengetahuan bagaimana mengelola kelas pada saat peserta didik melakukan percobaan, terutama pengawasan penggunaan alat yang mudah pecah, mudah rusak dan proses pembimbingan peserta didik dalam melakukan percobaan.

Aspek negatif atau hambatan kegiatan pelatihan menurut peserta waktu pelatihan yang singkat sehingga tidak dapat mencoba semua alat pada KIT yang ada.

\section{Kesimpulan}

Berdasarkan hasil kegiatan pengabdian kepada masyarakat yang telah dilakukan oleh tim dapat disimpulkan sebagai berikut :

1. Guru sangat antusias dalam mengikuti kegiatan pelatihan dilihat dari respon posisitf guru dalam mengikuti kegiatan pelatihan untuk meningkatkan kompetensinya masing-masing terutatama kemampuan penggunaan KIT dalam pembelajaran IPA berbasis inkuiri.

2. Guru yang semulanya sangat awam dengan KIT IPA menjadi lebih mengetahui manfaat nya dalam pembelajaran, seperti mengetahui nama alat dan fungsiny, cara penggunaan untuk menemukan konsep IPA, cara mengelola percobaan IPA di kelas sehingga pembelajaran menjadi menarik dan menyenangkan.a

\section{Saran}

Saran yang diajukan berhubungan dengan hasil kegiatan pengabdian ini :

1. Untuk meningkatkan kemampuan penggunaan KIT dalam pembelajaran IPA berbasis inkuiri
e-ISSN : 2715-2537

p-ISSN : 2715-2545

guru diharapkan berlatih sendiri menggunakan KIT IPA bersama teman-teman sejawat untuk menemukan konsep-konsep IPA dan membuat perencanaan pembelajaran berbasis inkuiri berbantuan KIT dan mensimulasikan pembelajaran sebelum diterapkan ke peserta didik.

2. Pelaksanaan pengabdian untuk massa mendatang dapat dibuat dengan waktu pelatihan dan pendampingan yang lebih panjang sehingga guru dapat sepenuhnya memaksimalkan penggunaan KIT dalam pembelajaran.

\section{Ucapan Terima Kasih}

Tim pengabdian mengucapkan terima kasih kepada Lembaga Penelitian dan Pengbdian kepada Masyarakat Universitas Mataram dan SD Negeri 1 Cakranegara sebagai sekolah mitra, dan juga semua pihak yang telah memberi dukungan pelaksanaan terhadap pengabdian ini.

\section{Daftar Pustaka}

Abidin, Yunus. 2014. Desain Sistem Pembelajaran dalam Konteks Kurikulum 2013. PT. Refika Aditama : Bandung.

Asy'ari, Muslichach. 2006. Penerapan Sains Teknologi Masyarakat Dalam Pembelajaran Sains di SD. Depdiknas Dirjen Dikti Direktorat Ketenagaan.

Hikmawati, et. al. 2018. Pelatihan Penyusunan Lembar Kerja Peserta Didik Berbasis Inkuiri melalui Pola Lesson Studi Bagi Guru-Guru SMA https://prosidingpkmcsr.org/index.php/pkmcsr/article/view/ $\underline{121}$

Kemendikbud. 2014. Permendikbud No. 103 tentang Penilaian Hasil Belajar oleh Pendidik pada Pendidikan Dasar dan Pendidikan Menengah. Jakarta: Kementerian Pendidikan dan Kebudayaan.

Kurniasih, Imas. dan Sani. 2015. Ragam Pengembangan Model Pembelajaran. Jakarta: Kata Pena.

Poedjiati. 2005. Pengembangan Pembelajaran IPA Sekolah Dasar. Alfabeta : Bandung.

Rahman, S. 2019. Tuntutan Sebagai Guru dalam Pembelajaran di Era milenial, Tuntutan sebagai Guru dalam Pembelajaran di 
Sutrio et al, Jurnal Pengabdian Masyarakat Sains Indonesia 2020, 2 (2):147-153. DOI : https://doi.org/10.29303/jpmsi.v2i2.80

e-ISSN : 2715-2537

p-ISSN : 2715-2545

Era Milenial $\mid$ Blog Rumah Belajar (kemdikbud.go.id) diakses tanggal $23 \mathrm{Mei}$ 2020. 